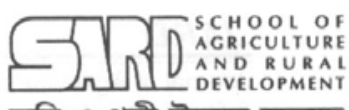

কৃষि 3 পब्की উन्नয়न অनूষদ
Available online at

http:/ / www.banglajol.info/index.php/jard
J ARD

Journal of Agriculture

\& Rural Development

\title{
Growth Response of Hydroponic Rice Seedlings at Elevated Concentrations of Potassium Chloride
}

\author{
M. R. SHAIBUR ${ }^{1}$, A. H. M. SHAMIM ${ }^{2 *} \&$ S. KAWAI $^{3}$ \\ ${ }^{1 \& 3}$ The United Graduate School of Agricultural Sciences, Iwate University, Morioka-0208550, Japan \\ ${ }^{2}$ School of Agriculture and Rural Development, Bangladesh Open University, Gazipur-1705, Bangladesh
}

\begin{abstract}
A hydroponic experiment was conducted in the greenhouse to observe the effect of potassium chloride $(\mathrm{KCl})$ on growth, macro elements and sodium ( $\mathrm{Na}$ ) concentration of rice seedlings (Oryza sativa $\mathrm{L}$. CV. Hitomebore). The plants were grown up to 14 days after treatments (DAT) treated with 0,10, 20 and $30 \mathrm{mM}$ $\mathrm{KCl}$. Shoot dry weight $(d w)$ decreased significantly in the $10 \mathrm{mM} \mathrm{KCl}$ treatment, indicated that rice seedlings were highly sensitive (glycophytes) to $\mathrm{KCl}$. However, root $\mathrm{dw}$ increased in the $10 \mathrm{mM} \mathrm{KCl}$ treatment as compared to other treatments, indicated that $\mathrm{KCl}$ could enhance root $\mathrm{dw}$ at lower concentration. The result indicated that the shoot of rice seedlings was highly sensitive to $\mathrm{KCl}$ than that of root. Shoot height, root length and leaf number decreased significantly in the 20 and $30 \mathrm{mM} \mathrm{KCl}$ treatments, while the width of leaf blade decreased significantly only in the $30 \mathrm{mM} \mathrm{KCl}$ treatment. Considering $10 \% \mathrm{dw}$ reduction the critical toxicity levels (CTL) of $K$ in shoot was $60.4 \mathrm{mg} \mathrm{g}^{-1} \mathrm{dw}$ and $23.3 \mathrm{mg} \mathrm{g}^{-1} \mathrm{dw}$ in root. Potassium chloride decreased calcium (Ca), magnesium (Mg) and $\mathrm{Na}$ concentrations both in shoot and root, indicated that $K$ had antagonistic relationships with $\mathrm{Ca}, \mathrm{Mg}$ and $\mathrm{Na}$ in rice seedlings. Phosphorus $(P)$ concentration decreased in shoot in the $30 \mathrm{mM} \mathrm{KCl}$ treatment indicated that the toxic effete of $\mathrm{KCl}$ on P. Potassium concentrations increased in shoot and root with the increasing $\mathrm{KCl}$ concentrations in the nutrient solution. The sensitivity response of the elements in rice was $\mathrm{Na}>\mathrm{Mg}>\mathrm{Ca}>\mathrm{P}$ under elevated concentrations of $\mathrm{KCl}$.
\end{abstract}

Key words: Calcium, hydroponic, magnesium, potassium, potassium chloride, rice, sodium.

\section{INTRODUCTION}

Some plants could encounter salt stress, but most plants are affected adversely by high levels of salt. Excess salts commonly cause a reduction in growth and yield of most agricultural crops. It was considered that reduction is due to direct effects of ions on photosynthesis that led to reduce growth. The effect of salt on growth reduction is not uniform among ions; some are more toxic than the others. The toxicity of an equamolar concentration of one ionic species is greater than that of a combination of ions (Bernstein, 1975). Although the enzymes of glycophytes (salt sensitive) and halophytes (salt resistant) are equally sensitive to salts, the effects of soil solution salts on plant metabolism vary among ionic species and between glycophytes and halophytes. In glycophytes, $\mathrm{Na}^{+}$salts are more toxic than $\mathrm{K}^{+}$salts, while in halophytes, toxicity follows the general pattern: $\mathrm{K}_{2} \mathrm{SO}_{4}>\mathrm{KCl}>\mathrm{Na}_{2} \mathrm{SO}_{4}=\mathrm{NaCl}$ (Egan and Ungar, 1998).

The mentioned salts could be accumulated in soils and severely inhibit plant growth. They induce plasmolysis (water moves out of the plant into the solution) (Tan, 1998). Intensive research

\footnotetext{
*Corresponding author: Assistant Professor (Soil Science), SARD, BOU, Gazipur-1705, E-mail: abulhasnats@yahoo.com

(C) 2008 School of Agriculture and Rural Development, Bangladesh Open University, All rights reserved.
} 
began in the 1950s, when the U.S. salinity lab showed that some plants can grow faster with low salt content in their tissues and the shoot salts are controlled by the root (Orcutt and Nilsen, 2000). More than 100 plant families contain salt-tolerant species (Aronson, 1989). Most of the families contain less than 10 salt tolerant species, but Chenopodiaceae contains over 350 (Orcutt and Nilsen, 2000). Salts of the soil solution govern the salinity properties of soils. On the basis of salinity tolerance plants can be classified into two broad groups (1) Glycophytes: these plants are sensitive to relative low soil salt concentration. Most of the agricultural crops and higher plants are glycophytes. Among crops, maize, onion, citrus, pecan, lettuce and bean are highly sensitive to salt (Taiz and Zeiger, 2002). Glycophytes can be classified as (a) Euglycophytes or true glycophytes or strict glycophytes or sensitive glycophytes or intolerant glycophytes: a plant whose growth and fitness decreases when expose to any level of salinity (less than approximately $10 \mathrm{mM}$ ) (b) Obligate or Normal glycophytes: these plants can tolerate a very low salinity but can't tolerate soil salinity greater than approximately $10 \mathrm{mM}$ (2) Halophytes: plants those are able to grow in the presence of high salt condition. These plants often require some salt to grow their best. It is considered that more than one-third of extant plant families have halophytic members and about 250 species of halophytes are found in the world's salt marshes and desert flats (Glenn, 1997). Halophytes can be classified as (a) Euhalophytes or true halophytes or strict halophytes: halophytes could grow in conditions of extreme high salinity (more than $50 \mathrm{mM}$ ) before a reduction in growth or fitness (b) Obligate halophytes: plants that require salt in the growth medium to reach their maximum growth potential and have their highest fitness. This type of plant does not attain their highest fitness at low soil salinity (less then 10 $\mathrm{mM})$. Moderately high soil salinity $(50 \mathrm{mM})$ is required to attain maximum fitness (c) Facultative halophytes: these plants attain a halophytic nature only after experience moderate salinity in the soils or as an aerosol. Until now, many researches have been done to classify the plants related to salt tolerance activity. Most of which were conducted with $\mathrm{Na}$ and its derivatives together with other salt, but the data of $\mathrm{KCl}$ research in hydroponic culture were not adequate. Therefore, the present experiment was conducted to define the classification of Hitomebore rice variety together with its macroelements and $\mathrm{Na}$ under elevated concentrations of $\mathrm{KCl}$.

\section{MATERIALS AND METHODS}

\section{Seedling preparation and plant culture}

Rice seeds were (Oryza sativa L. cv. Hitomebore) surface sterilized with $2 \%(\mathrm{w} / \mathrm{v})$ chlorinated lime $\left[\mathrm{Ca}(\mathrm{OCl})_{2}\right]$ for 45 minutes, rinsed with tap water continuously for 1 hour and soaked between moistened towels covered with wrapping paper at $25^{\circ} \mathrm{C}$ for 72 hours in an electric incubator. Germinated seeds were placed on plastic net in the seed box containing $2 \mathrm{mM} \mathrm{CaCl}_{2}$ solution in the greenhouse of Iwate University, Morioka, Japan. After 7 days, the chlorinated solution in the seed box was replaced with $1 / 2$-strength modified Hoagland-Arnon nutrient solution for rice (Hewitt and Smith, 1975). This was done 2 times before starting the treatments. A total of 24 days were required for the seedling preparation. All plants were allowed to grow until $5^{\text {th }}$ full leaf and some plants also contained $6^{\text {th }}$ leaf at emergence stage. After 24 days, seedlings were transplanted in bunches ( 5 plants were wrapped with sponge rubber to make 1 bunch) and 8 bunches were placed in one pot (capacity 5 liters) filled with full strength rice solution containing $10 \mu \mathrm{M} \mathrm{Fe}{ }^{3+}$-citrate. The plants were treated with $\mathrm{KCl}$ up to 14 days after treatments (DAT). The treatments of $\mathrm{KCl}$ were 0 , 10,20 and $30 \mathrm{mM}$. The plants were grown in the greenhouse and the $\mathrm{pH}$ of the solutions was 5.5 at the time of solution preparation. The nutrient solutions were renewed every week during the study (July 22, 2005 to August 28, 2005).

\section{Compositions of full-strength nutrient solution}

The compositions of the full-strength nutrient solutions were $1 \mathrm{mM} \mathrm{NH}_{4} \mathrm{NO}_{3}, 1 \mathrm{mM} \mathrm{K}_{2} \mathrm{SO}_{4}, 0.8 \mathrm{mM}$ $\mathrm{MgSO}_{4}, 0.5 \mathrm{mM} \mathrm{CaCl}_{2}, 0.5 \mathrm{mM} \mathrm{NaH}_{2} \mathrm{PO}_{4}, 10 \mu \mathrm{M} \mathrm{MnSO}_{4}, 1 \mu \mathrm{M} \mathrm{CuSO}_{4}, 1 \mu \mathrm{M} \mathrm{ZnSO}_{4}, 3 \mu \mathrm{M} \mathrm{H} \mathrm{BO}_{3}$, $0.05 \mu \mathrm{M} \mathrm{H}_{2} \mathrm{MoO}_{4}$ and $10 \mu \mathrm{M} \mathrm{Fe}^{3+}$-citrate.

\section{Sample collection and preparation}

After 14 DAT, 3 bunches were taken from each treatment for determining some growth parameters and $\mathrm{P}, \mathrm{K}, \mathrm{Ca}, \mathrm{Mg}$ and $\mathrm{Na}$. The plants were washed with deionized water properly and separated into shoot 
and root with sterilized scissor and were dried for 48 hours at $55-60^{\circ} \mathrm{C}$ in an electric oven (ISUZU, Isuzu Seisakusho Company, Tokyo, Japan). The samples were cut into small pieces and digested with nitricperchloric acid mixture (Piper, 1942) and analyzed.

\section{Shoot height, root length and width of leaf blade}

Shoot height was measured from the culm base to the tip of the longest leaf and root length was measured from the root-shoot junction to the tip of the longest root (Abedin and Meharg, 2002). The width of leaf blade was measured in the middle position of fully developed sixth leaf with scale.

\section{Chlorophyll index (SPAD value)}

The chlorophyll index of fully developed leaves (sixth) on 14 DAT was measured using a SPAD502 chlorophyll meter (Minolta Camera Company, Tokyo, Japan). In each leaf the chlorophyll index of 5 points were measured and the average was calculated. Means of each bunch were obtained. Average of the data of 3 bunches was calculated.

\section{Chemical analysis}

Phosphorus was determined colorimetrically using a UV-visible Spectrophotometer (model UV mini 1240, Shimadzu Corp., Kyoto, Japan) at $420 \mathrm{~nm}$ wavelengths after developing the yellow color with vanadomolybdate as described by Barton (1948) and Jackson (1958). Potassium, Ca, Mg and Na were determined with the Hitachi 170-30 atomic absorption spectroscopy (AAS) (Hitachi, Tokyo, Japan).

\section{Experimental design}

The experiment was a completely randomized block design with 3 replications. Data were analyzed by analysis of variance (SAS, 1990).

\section{Calculation procedure}

Relative shoot weight in \% (RSW) $=$ (shoot weight of a specific treatment/shoot weight of control treatment) $\times 100$. Relative root weight in \% $(\mathrm{RRW})=$ (root weight of a specific treatment/root weight of control treatment) $\times 100$. Concentration of elements in plant tissue refers to the element present in one $\mathrm{g}$ of sample [mg or $\mu \mathrm{g}$ of the element $\mathrm{g}^{-1}$ dry weight (dw)] while accumulation refers to the specific element present per plant shoot or root $\left(\mathrm{mg}\right.$ or $\mu \mathrm{g}$ of the element plant ${ }^{-1}$ shoot or root). Uptake is being considered as the total accumulation (accumulation in shoot plus accumulation in root). Translocation (\%) could be expressed in nutrient accumulation in shoot $x$ $100 /$ total accumulation (shoot + root).

\section{Reagents}

All chemicals used were of analytical reagent grade. All solutions were prepared previously with $\mathrm{MQ}$ water [(18.2 $\left.\mathrm{M} \Omega \mathrm{cm}^{-1}\right)$, purified by Milli-RO 60, Millipore corporation, USA]. Stock solution of 3 $\mathrm{M} \mathrm{KCl}$ was prepared by dissolving $\mathrm{KCl}$ salt (Kanto Chemical Company, Tokyo, Japan) in MQ water. This stock solution was kept at room temperature in an acid washed reagent bottle in the laboratory in normal condition. Working solutions of $0,10,20$ and $30 \mathrm{mM} \mathrm{KCl}$ were prepared every week by diluting the stock solution with deionized water. Glassware used for this experiment was soaked in $0.1 \mathrm{~N}$ nitric acid solutions and were rinsed with $\mathrm{MQ}$ water.

\section{RESULTS AND DISCUSSION}

\section{Visible symptoms}

Severe necrotic symptom (burning of young leaf tips and death associated with discoloration and dehydration of old leaves) was visualized in the leaves of $30 \mathrm{mM} \mathrm{KCl}$ treatment. In the $30 \mathrm{mM} \mathrm{KCl}$ treatment, the older leaves died completely. Yellowing of younger leaf increased with the severity of $\mathrm{KCl}$ concentrations. Greening of the leaves decreased with increasing $\mathrm{KCl}$ concentrations in the nutrient solution, this was most probably due to the reduction of chlorophyll content in the leaves. The youngest leaves failed to unfold, leaf size (length and width) decreased drastically and visible growth reductions were found in the $30 \mathrm{mM} \mathrm{KCl}$ treatment. Curling of the younger leaves followed by shriving occurred. The most common symptom, however, was growth reduction. Potassium chloride toxicity resulted in poor root length, reddish discoloration and felt 'slippery' to touch may be 
due to deterioration of the middle lamella by excess K. Potassium could interfere physiological availability of $\mathrm{Ca}$ (Marschner, 1998) which may lead root function disruption. In this experiment, root length increased in the $10 \mathrm{mM} \mathrm{KCl}$ treatment, indicated that low concentration of $\mathrm{KCl}$ enhanced root elongation which was most probably due to the positive effect of chlorine (Brady and Weil, 2002). The result of the present study indicated that at high level of availability of $\mathrm{KCl}$ resulted in harmful physiological response in the rice seedlings tissues (toxicity range).

\section{Chlorophyll index (SPAD value)}

In the present experiment, the chlorophyll index decreased with the increasing $\mathrm{KCl}$ concentrations in the nutrient solution (data not shown), indicated that excess $\mathrm{KCl}$ reduced the production of chlorophyll content in the leaves.

\section{Dry matter yield}

Potassium chloride decreased shoots $\mathrm{dw}$ in the 10,20 and $30 \mathrm{mM} \mathrm{KCl}$ treatments. However, root $\mathrm{dw}$ increased in the $10 \mathrm{mM} \mathrm{KCl}$ treatment, but decreased in the 20 and $30 \mathrm{mM} \mathrm{KCl}$ treatments (Fig. 1a). The highest shoot $d w$ was recorded in the control and the lowest was in the $30 \mathrm{mM} \mathrm{KCl}$ treatments, respectively. Potassium chloride in the nutrient solution was accountable for 10,19 and $27 \%$ shoot dry matter yield reduction in the 10,20 and $30 \mathrm{mM} \mathrm{KCl}$ treatments, respectively. However, $10 \% \mathrm{dw}$ increased in root in the $10 \mathrm{mM} \mathrm{KCl}$ treatment [this was most probably due to the positive effect of $\mathrm{Cl}$ on root length (Brady and Weil, 2002)] while 19 and $24 \%$ dw decreased in the 20 and $30 \mathrm{mM} \mathrm{KCl}$ treatments, respectively. Our experimental data indicated that the rice seedlings were $\mathrm{KCl}$ sensitive (obligate glycophytes) and shoot was more sensitive than that of root. 10 20 $\mathrm{mM} \mathrm{KCl}$ could be the limiting factor for shoot of rice seedlings in the hydroponic culture. Growth reduction was most probably due to the toxic effects of $\mathrm{KCl}$ on enzymatic activity. It is reported that the enzymes of glycophytes and halophytes (Greenway and Osmond, 1972; Greenway and Munns, 1980 ) are inhibited by salt in vitro equally. We calculated 100, 94, 81 and $73 \%$ RSW and 100, 110, 81 and $76 \%$ of RRW for $0,10,20$ and $30 \mathrm{mM} \mathrm{KCl}$ treatments, respectively, indicated that with an increase of $\mathrm{KCl}$ levels reduced the relative growth.

\section{Shoot height and root length}

Shoot height decreased with increasing $\mathrm{KCl}$ in the nutrient solution and the lowest value was recorded in the $30 \mathrm{mM} \mathrm{KCl}$ treatment. In $10 \mathrm{mM} \mathrm{KCl}$ treatment, root length increased significantly as compared to other treatments (Fig. 1b). This increase was most probably due to the positive effect of $\mathrm{Cl}$ on root length (Brady and Weil, 2002). However, the root length decreased significantly in 20 and $30 \mathrm{mM} \mathrm{KCl}$ treatments. In the higher $\mathrm{KCl}$ treatments, Ca concentrations decreased in root (Fig. 2c). The reduction of $\mathrm{Ca}$ concentrations might be involved to reduce the root length, because $\mathrm{Ca}$ is mainly related to root elongation. Under normal conditions, the cytosol of higher-plant cells contains $100-200 \mathrm{mM} \mathrm{K}^{+}$and 1 to $10 \mathrm{mM} \mathrm{Na}^{+}$an ionic environment in which many enzymes function optimally (Marschner, 1998). In presence of high $\mathrm{KCl}(30 \mathrm{mM})$, an abnormally high ratio of $\mathrm{K}^{+}$and high concentrations of total salts may inactivate enzymes and inhibits protein synthesis. At higher concentrations of $\mathrm{K}^{+}, \mathrm{K}^{+}$may displace $\mathrm{Ca}^{2+}$ from the plasma membrane of rice root hairs, resulted in a change in plasma membrane permeability. Cramer et al. (1985) found Ca was replaced by $\mathrm{Na}$ in cotton roots and decreased the normal function of root.

\section{Leaf number}

Leaf number decreased significantly in 20 and $30 \mathrm{mM} \mathrm{KCl}$ treatments. The highest leaf number was recorded in the control treatment and the lowest was in the $30 \mathrm{KCl}$ treatments (Fig. 1c). This was most probably due to the reduced plant growth hormone production or an increase in the production of abscisic acid (ABA) (Nilsen and Orcutt, 1996). This supposition needs to be verified in the future. This reduction of leaf number might be responsible for the reduction of shoot $\mathrm{dw}$ (Fig. 1a).

\section{Width of leaf blade}

The width of leaf blade decreased significantly in the $30 \mathrm{mM} \mathrm{KCl}$ treatment. The highest width of leaf blade was recorded in control treatment and the lowest was recorded in $30 \mathrm{mM} \mathrm{KCl}$ 
treatments, respectively (Fig. 1c). This was most probably due to the fact that $\mathrm{KCl}$ reduced the activity of plant growth regulators. It was found that protein synthesis is reduced in soybean leaves growing in $\mathrm{NaCl}$ saline condition which might be due to chloride toxicity in sensitive species (Marschner, 1998). Therefore, the other possible cause may be reduction of protein synthesis in the higher $\mathrm{KCl}$ concentration.

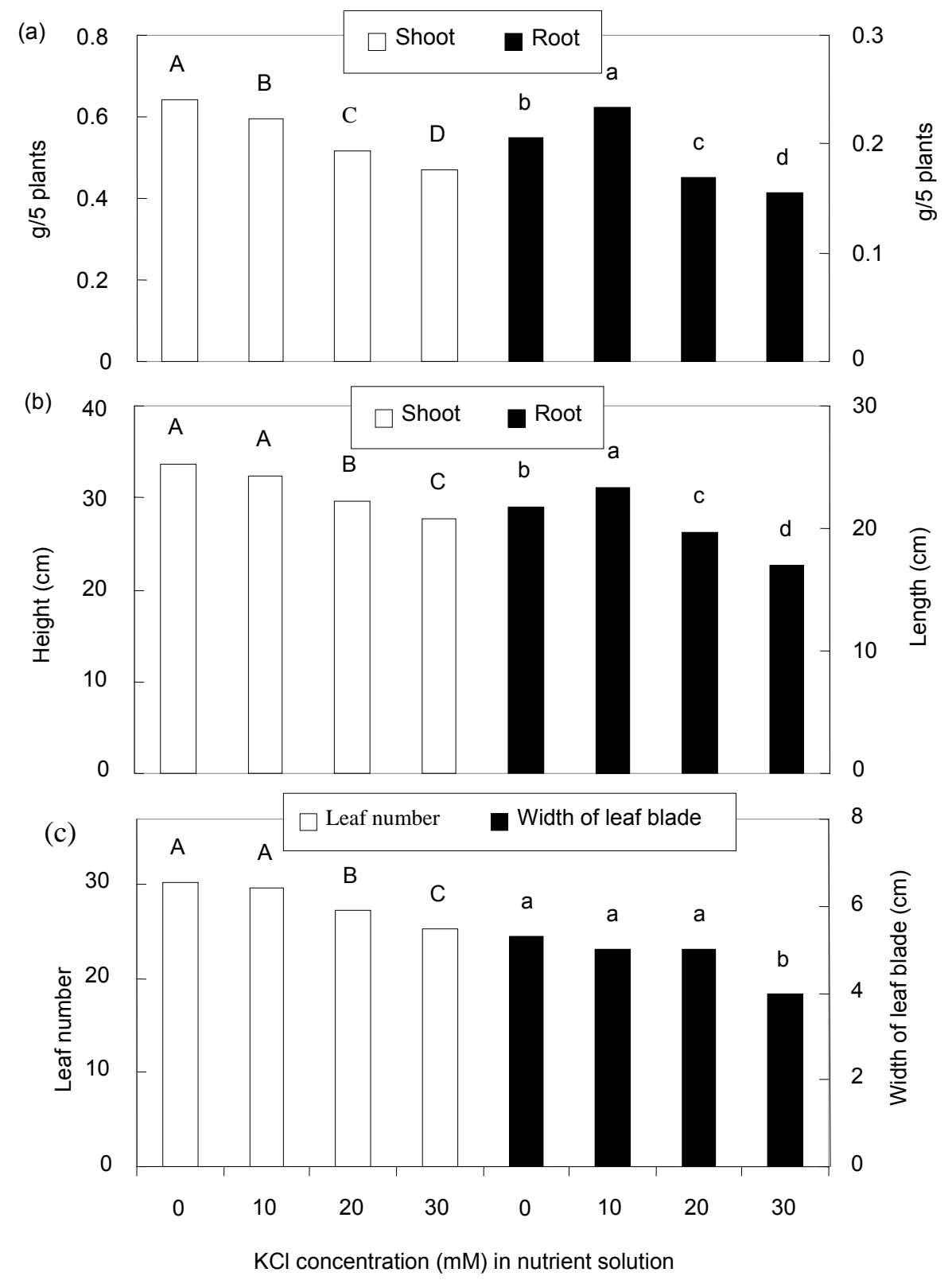

Fig 1. (a) Dry matter yield, (b) shoot height and root length; and (c) leaf number and width of leaf blade of rice seedlings with different levels of $\mathrm{KCl}$. Bars with different letters are significantly different $(p<0.05)$ according to a Ryan-Einot-Gabriel-Welsch multiple range test. 


\section{R. Shaibur et al.}

\section{Tiller number}

No new tiller was found even in the control treatment during the experiment (38 day after germination) or 14 DAT. Therefore, it was not wise to draw any comment related to effect of $\mathrm{KCl}$ on tiller formation. It could only be said that the time duration was not sufficient for the formation of new tiller in this experiment.

\section{Effect of $\mathrm{KCl}$ on phosphorus}

The concentrations of $\mathrm{P}$ did not change in shoot in 10 and $20 \mathrm{mM}$ of $\mathrm{KCl}$ treatments as compared to control treatment, but decreased significantly in the $30 \mathrm{mM} \mathrm{KCl}$ treatment (Fig. 2a). This reduction was most probably due to severe toxicity of $\mathrm{KCl}$ on plant growth. Chlorine is one of the non-metal micronutrients and because of its non-metallic character, it is similar to P. Due to this chemical similarity a competitive process in their uptake could be expected. In the case of root, the concentration decreased significantly in the $10 \mathrm{mM} \mathrm{KCl}$ treatment, which was most probably due to dilution effect, because in this treatment root $\mathrm{dw}$ and length increased significantly. For other treatments no change of $\mathrm{P}$ concentrations were found. Phosphorus concentrations decreased $12 \%$ in shoot and $9 \%$ in root in $30 \mathrm{mM} \mathrm{KCl}$ treatment in the nutrient solution. The accumulation also decreased significantly in shoot and root in the $30 \mathrm{mM} \mathrm{KCl}$ treatment which indicated the toxic effect (Table 1). Phosphorus and $\mathrm{K}$ ratio in shoot and root decreased significantly with the $\mathrm{KCl}$ treatments indicated the negative effect of $\mathrm{KCl}$ on $\mathrm{P}$ concentration (Table 2). Typical $\mathrm{P}$ concentrations in common plants are 2-4 $\mathrm{mg} \mathrm{g}^{-1} \mathrm{dw}$ (Liao et al., 2004) or 3-4 $\mathrm{mg} \mathrm{g}^{-1} \mathrm{dw}$ (Mengel and Kirkby, 2001) during the vegetative growth stage, indicated that the $P$ concentrations of the experimental plants was higher (Fig. 2a), this was most probably due to species of rice seedlings. Phosphorus translocation was not much affected in this experiment by the used $\mathrm{KCl}$ in the nutrient solution (Table 1).

Table 1. Accumulation (mg plant ${ }^{-1}$ shoot or root) in shoot and root and translocation (\%) from root to shoot of nutrient elements of rice seedlings grown in nutrient solution at different levels of $\mathrm{KCl}$

\begin{tabular}{|c|c|c|c|c|c|c|c|c|c|c|}
\hline & \multicolumn{10}{|c|}{ Accumulations (mg plant ${ }^{-1}$ shoot or root) } \\
\hline Treatments & \multicolumn{2}{|c|}{$P$} & \multicolumn{2}{|c|}{$\mathrm{K}$} & \multicolumn{2}{|c|}{$\mathrm{Ca}$} & \multicolumn{2}{|c|}{$\mathrm{Mg}$} & \multicolumn{2}{|c|}{$\mathrm{Na}$} \\
\hline$(\mathrm{mM} \mathrm{KCl})$ & Shoot & Root & Shoot & Root & Shoot & Root & Shoot & Root & Shoot & Root \\
\hline 0 & $1.35 \mathrm{~A}$ & $0.26 a$ & $4.61 \mathrm{C}$ & $0.65 d$ & $0.44 \mathrm{~A}$ & $0.015 a$ & $0.41 \mathrm{~A}$ & $0.027 a$ & $0.30 \mathrm{~A}$ & $0.18 a$ \\
\hline 10 & $1.31 \mathrm{~A}$ & $0.24 a$ & 7.47B & $0.83 \mathrm{~b}$ & $0.37 \mathrm{~B}$ & $0.013 \mathrm{~b}$ & $0.40 \mathrm{~A}$ & $0.026 a$ & $0.20 \mathrm{~B}$ & $0.09 \mathrm{~b}$ \\
\hline 20 & $1.06 \mathrm{~B}$ & $0.23 a$ & $7.93 \mathrm{~B}$ & $0.93 a$ & $0.27 \mathrm{C}$ & $0.012 \mathrm{~b}$ & $0.26 \mathrm{~B}$ & $0.020 \mathrm{~b}$ & $0.14 \mathrm{C}$ & $0.09 \mathrm{~b}$ \\
\hline 30 & $0.88 \mathrm{C}$ & $0.18 \mathrm{~b}$ & $8.72 \mathrm{~A}$ & $0.77 \mathrm{c}$ & $0.25 \mathrm{D}$ & $0.008 \mathrm{c}$ & $0.21 \mathrm{C}$ & $0.014 \mathrm{c}$ & $0.14 \mathrm{C}$ & $0.06 \mathrm{c}$ \\
\hline $\mathrm{mM} \mathrm{KCl}$ & \multicolumn{10}{|c|}{ Translocation (\%) } \\
\hline 0 & \multicolumn{2}{|c|}{$84 \mathrm{~A}$} & \multirow{2}{*}{\multicolumn{2}{|c|}{$88 \mathrm{~A}$}} & \multirow{2}{*}{\multicolumn{2}{|c|}{$97 \mathrm{~A}$}} & \multirow{2}{*}{\multicolumn{2}{|c|}{$94 \mathrm{~A}$}} & \multirow{2}{*}{\multicolumn{2}{|c|}{$64 \mathrm{~A}$}} \\
\hline 10 & \multirow{2}{*}{\multicolumn{2}{|c|}{$\begin{array}{l}85 \mathrm{~A} \\
82 \mathrm{~A}\end{array}$}} & & & & & & & & \\
\hline 20 & & & \multicolumn{2}{|c|}{$90 \mathrm{~A}$} & \multicolumn{2}{|c|}{$96 \mathrm{~A}$} & \multicolumn{2}{|c|}{$93 \mathrm{~A}$} & \multicolumn{2}{|c|}{$55 \mathrm{~B}$} \\
\hline 30 & \multicolumn{2}{|c|}{$83 \mathrm{~A}$} & \multicolumn{2}{|c|}{$92 \mathrm{~A}$} & \multicolumn{2}{|c|}{$97 \mathrm{~A}$} & \multicolumn{2}{|c|}{$94 \mathrm{~A}$} & \multicolumn{2}{|c|}{$55 \mathrm{~B}$} \\
\hline
\end{tabular}

${ }^{a}$ Means followed by the different letters in each column are significantly different $(p=0.05)$

\section{Effect of $\mathrm{KCl}$ on potassium}

Potassium concentrations increased significantly both in shoot and root with the increasing $\mathrm{KCl}$ concentrations in the nutrient solution (Fig. 2b). In shoot, the highest concentration was recorded in the $30 \mathrm{mM} \mathrm{KCl}$ treatment. Not only concentration but also accumulation increased in shoot with treatments (Table 1). In the highest concentration of $\mathrm{KCl}$ in the nutrient solution, the translocation of $\mathrm{K}$ from root to shoot did not increase markedly (Table 1 ). The increase of $K$ concentration and accumulation in shoot and in root might be due to "luxury consumption" of K (Marschner, 1998) which is a normal phenomenon in high level of $\mathrm{K}$ supply. The $\mathrm{K}$ content increased in various organs [except grains and seeds which maintain relatively constant $K$ content of $0.3 \%$ of the $\mathrm{dw}$ ] by increasing the $\mathrm{K}$ supply to plant root (Marschner, 1998). The value of $\mathrm{K}$ concentration is $1-4 \%$ (10$40 \mathrm{mg} \mathrm{K} \mathrm{g}^{-1} \mathrm{dw}$ ) of dw in healthy leaf tissue of most plants (Brady and Weil, 2002). However, it was also pointed out that $\mathrm{K}$ requirement for optimal plant growth is in the range of $2-5 \%\left(20-50 \mathrm{mg} \mathrm{g}^{-1}\right.$ 
$\mathrm{dw}$ ) of plant vegetative parts, fleshy fruits and tubers (Marschner, 1998). In the highest concentration of $\mathrm{KCl}$, the plants absorb high concentrations of $\mathrm{K}$, resulted in the toxicity symptoms. At high level of availability of an element, the plant will take up a large amount of the nutrient elements for its own good (toxicity range), result harmful physiological reactions in the plant cell. In this experiment, the $\mathrm{K}$ concentration in shoot of control seedlings was $35.9 \mathrm{mg} \mathrm{g}^{-1} \mathrm{dw}$, indicated the normal concentration of $\mathrm{K}$ in shoot tissues. It was also reported that $\mathrm{K}$ concentration in shoot of hydroponic rice was $44.1 \mathrm{mg} \mathrm{g}^{-1} \mathrm{dw}$ (Shaibur et al., 2006) and $60.2 \mathrm{mg} \mathrm{g}^{-1} \mathrm{dw}$ in hydroponic barley (Alam et al., 2001) of control plants.

\section{Effect of $\mathrm{KCl}$ on calcium}

Calcium concentrations decreased both in shoots and roots with the increasing $\mathrm{KCl}$ concentrations in the nutrient solution. The significant reductions were obtained in 20 and $30 \mathrm{mM} \mathrm{KCl}$ treatments (Fig. 2c). It is well known that $\mathrm{KCl}$ in solution is dissociated as $\mathrm{K}^{+}$and $\mathrm{Cl}^{-}$ions. As $\mathrm{K}^{+}$and $\mathrm{Ca}^{2+}$ both are cations, therefore, antagonistic relationships between them could be possible. Our result showed that the antagonistic relationship between $\mathrm{K}^{+}$and $\mathrm{Ca}^{2+}$; and the $\mathrm{Ca}$ concentrations decreased by $22 \%$ in shoot and $27 \%$ in root in the $30 \mathrm{mM} \mathrm{KCl}$ treatment. When the $\mathrm{K}$ supply is abundant in the rooting medium "luxury consumption" of $\mathrm{K}$ often occurs which deserve attention for its possible interference with the uptake and physiological availability of $\mathrm{Ca}$ and $\mathrm{Mg}$ (Marschner, 1998). Calcium stabilizes cell membranes by bridging phosphate and carboxylate groups of phospholipids (Caldwell and Haug, 1981) and preferentially protein at membrane surfaces (Legge et al., 1982). There can be an exchange between $\mathrm{Ca}$ at these binding sites and other cations (eg. $\mathrm{K}^{+}, \mathrm{Na}^{+}$or $\mathrm{H}^{+}$) resulted in $\mathrm{Ca}$ concentrations decreased. Calcium accumulations were also decreased significantly by the $\mathrm{KCl}$ treatments but the translocation was not affected much (Table 1). Calcium concentration in plant tissues varies between $0.1->5 \%\left(1-50 \mathrm{mg} \mathrm{Ca} \mathrm{g}^{-1} \mathrm{dw}\right)$ of $\mathrm{dw}$ depending on the growing conditions, plant species and plant organ (Marschner, 1998). The experimental plants contained 3.44, 3.12, 2.64 and $2.68 \mathrm{mg} \mathrm{Ca} \mathrm{g}^{-1} \mathrm{dw}$ in shoot tissues in 0, 10, 20 and $30 \mathrm{mM} \mathrm{KCl}$ treatments, respectively, indicated that the normal levels of Ca concentrations. The highest $\mathrm{Ca} / \mathrm{K}$ ratio was obtained (both in shoot and root) in control treatment and the lowest was in $30 \mathrm{mM} \mathrm{KCl}$ treatment, indicated that the lowest $\mathrm{Ca}$ concentration was in the highest $\mathrm{KCl}$ concentration in the nutrient solution. The hydrated $\mathrm{K}^{+}$has a radius of $0.331 \mathrm{~nm}$, but $\mathrm{Ca}^{2+}$ has the ionic radius of $0.099 \mathrm{~nm}$ (Marschner, 1998). Therefore, $\mathrm{K}$ strongly substitutes or competes with $\mathrm{Ca}^{2+}$ in various reactions involving either of these ions.

\section{Effect of $\mathrm{KCl}$ on magnesium}

Marginal concomitant relationship was found between $\mathrm{K}$ and $\mathrm{Mg}$ in shoot in the $10 \mathrm{mM} \mathrm{KCl}$ treatment (Fig. 2d). It may be due to the concentration effect because shoot $d w$ decreased significantly in this treatment (Fig. 1a). Magnesium concentrations decreased significantly in shoot in 20 and $30 \mathrm{mM}$ treatments and in root in 10,20 and $30 \mathrm{mM} \mathrm{KCl}$ treatments. This is logical because $\mathrm{K}^{+}$and $\mathrm{Mg}^{2+}$ both are cations, therefore, antagonistic relationship between them might be occurred. Some reports indicated that the $\mathrm{Mg}$ uptake can strongly be depressed by $\mathrm{K}^{+}$and $\mathrm{NH}_{4}^{+}$ (Kurvits and Kirkby, 1980), $\mathrm{Ca}^{2+}$ and $\mathrm{Mn}^{2+}$ (Heenan and Campbell, 1981) as well as by $\mathrm{H}^{+}$. Magnesium concentration decreased by $30 \%$ in shoot and $33 \%$ in root in $30 \mathrm{mM} \mathrm{KCl}$ treatment in the nutrient solution. The data presented in Table 1 showed that the accumulation of $\mathrm{Mg}$ was also depressed by the used $\mathrm{KCl}$ treatments, indicated that the antagonistic relationship between $\mathrm{K}$ and $\mathrm{Mg}$, however, the translocation of $\mathrm{Mg}$ was not affected by $\mathrm{KCl}$ (Table 1). The $\mathrm{Mg}$ and $\mathrm{K}$ ratio in shoot and in root decreased significantly with the $\mathrm{KCl}$ treatments (Table 2). In presence of excess available K, K may be taken up as high level (Marschner, 1998) which interfering the uptake and physiological availability of $\mathrm{Mg}$, resulted in the decrease in the $\mathrm{Mg} / \mathrm{K}$ ratio in the present experiment. In leaf tissues, the threshold value for the occurrence of Mg-deficiency symptoms is in the region of about $2 \mathrm{mg} \mathrm{g}^{-1} \mathrm{dw}$ (Mengel and Kirkby, 2001). The test plants contained 3.18, 3.40, 2.54 and $2.22 \mathrm{mg} \mathrm{Mg} \mathrm{g}^{-1} \mathrm{dw}$ in $0,10,20$ and $30 \mathrm{mM} \mathrm{KCl}$ treatments, respectively, indicated that the value in shoot tissues was over the critical deficiency level of $\mathrm{Mg}$. It was also reported that the $\mathrm{Mg}$ requirement for optimum plant growth is in the range of $0.15-0.35 \%\left(1.5-3.5 \mathrm{mg} \mathrm{Mg} \mathrm{g}^{-1} \mathrm{dw}\right)$ of the vegetative parts (Marschner, 1998), indicated that the shoot of the experimental plants contained more or less normal concentrations of $\mathrm{Mg}$. Potassium has a hydrated radius of $0.331 \mathrm{~nm}$ and $\mathrm{Mg}^{2+}$ 


\section{R. Shaibur et al.}

has the radius of $0.065 \mathrm{~nm}$ (Marschner, 1998). As a result, Mg could be replaced strongly by $\mathrm{K}$ in various reactions in this present experiment.
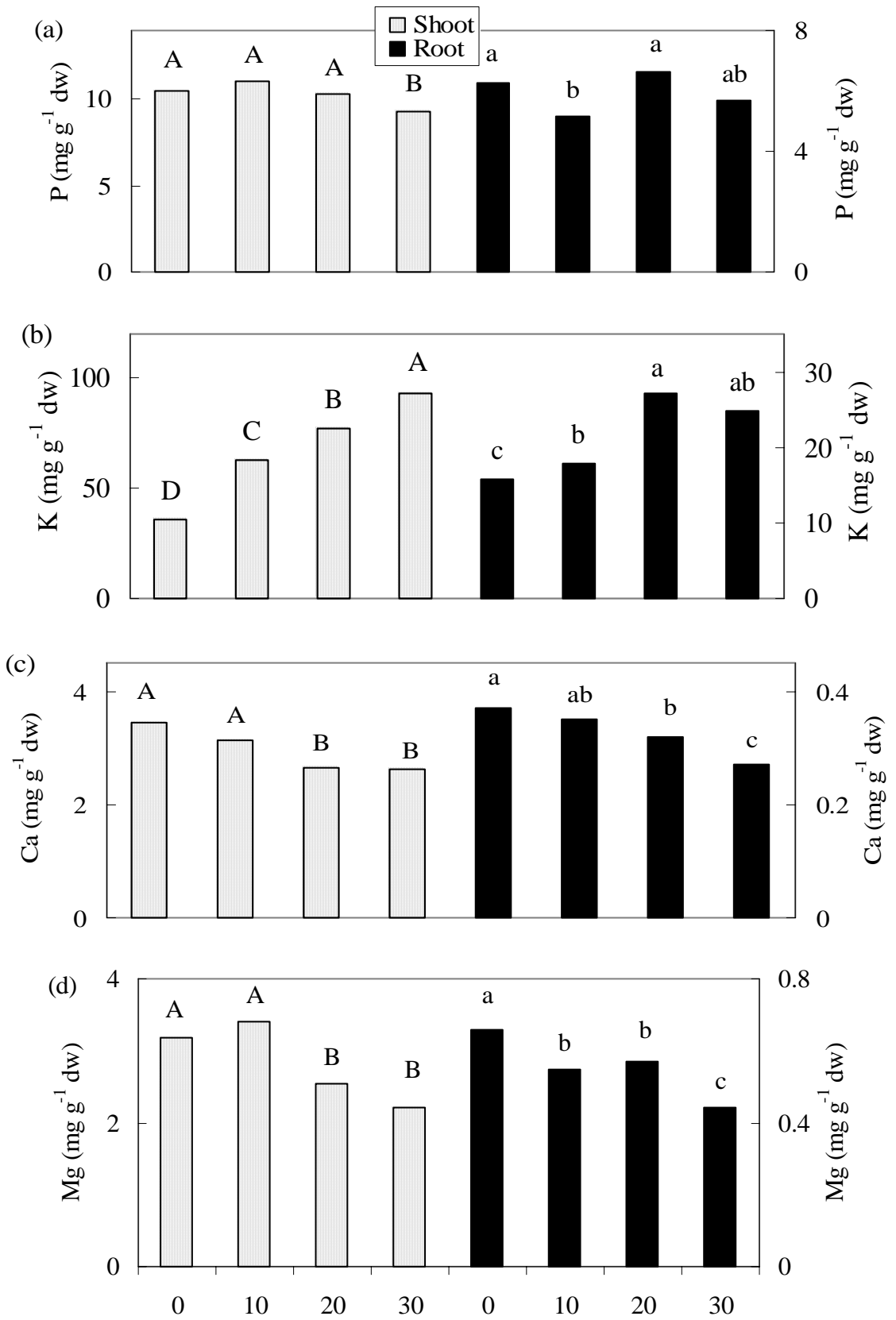

$\mathrm{KCl}$ concentration $(\mathrm{mM})$ in nutrient solution

Fig 2. Effect of $\mathrm{KCl}$ on the concentration of (a) $\mathrm{P}$, (b) $\mathrm{K}$, (c) $\mathrm{Ca}$ and (d) $\mathrm{Mg}$ in shoot and root of rice seedlings. Bars with different letters are significantly different $(p<0.05)$ according to a Ryan-Einot-Gabriel-Welsch multiple range test. 
Table 2. Concentration ratio of elements in shoot and in root of rice seedlings grown in nutrient solution at different levels of $\mathrm{KCl}$

\begin{tabular}{ccccccccc}
\hline Treatments & \multicolumn{2}{c}{$\mathrm{P} / \mathrm{K}$} & \multicolumn{2}{c}{$\mathrm{Ca} / \mathrm{K}$} & \multicolumn{2}{c}{$\mathrm{Mg} / \mathrm{K}$} & \multicolumn{2}{c}{$\mathrm{Na} / \mathrm{K}$} \\
\cline { 2 - 8 }$(\mathrm{mM} \mathrm{KCl})$ & Shoot & Root & Shoot & Root & Shoot & Root & Shoot & Root \\
\hline 0 & $0.293 \mathrm{~A}$ & $0.401 \mathrm{a}$ & $0.096 \mathrm{~A}$ & $0.023 \mathrm{a}$ & $0.087 \mathrm{~A}$ & $0.042 \mathrm{a}$ & $0.065 \mathrm{~A}$ & $0.279 \mathrm{a}$ \\
10 & $0.181 \mathrm{~B}$ & $0.291 \mathrm{~b}$ & $0.054 \mathrm{~B}$ & $0.015 \mathrm{~b}$ & $0.054 \mathrm{~B}$ & $0.031 \mathrm{~b}$ & $0.027 \mathrm{~B}$ & $0.114 \mathrm{~b}$ \\
20 & $0.134 \mathrm{C}$ & $0.241 \mathrm{c}$ & $0.034 \mathrm{C}$ & $0.013 \mathrm{~b}$ & $0.033 \mathrm{C}$ & $0.021 \mathrm{c}$ & $0.016 \mathrm{C}$ & $0.106 \mathrm{~b}$ \\
30 & $0.101 \mathrm{D}$ & $0.232 \mathrm{c}$ & $0.029 \mathrm{D}$ & $0.011 \mathrm{c}$ & $0.024 \mathrm{D}$ & $0.018 \mathrm{~d}$ & $0.015 \mathrm{C}$ & $0.078 \mathrm{c}$ \\
\hline
\end{tabular}

${ }^{a}$ Means followed by the different letters in each column are significantly different $(p=0.05)$

\section{Effect of $\mathrm{KCl}$ on sodium}

Sodium concentrations decreased significantly in shoot and root with the increasing $\mathrm{KCl}$ concentrations in the nutrient solution (Fig. 3), indicated that the severe antagonistic relationship between these two elements. Higher plants have developed high selectivity in the uptake of $\mathrm{K}$ as compared with that of $\mathrm{Na}$ and this is particularly obvious in transport to shoot (Marschner, 1998). For this reason "luxurious consumption of $\mathrm{K}$ " was taken place in the high $\mathrm{KCl}$ concentrations in the nutrient solution. Potassium has a more or less similar hydrous radius $(0.331 \mathrm{~nm})$ like $\mathrm{Na}^{+}(0.358$ $\mathrm{nm}$ ) (Marschner, 1998). In another way, it has also been pointed out that $\mathrm{Na}$ has the ionic radii of 1.65 2.05. $\AA$ while in $\mathrm{K}$ the ionic radii is 2.350 2.66 $\AA$ (Biggin et al., 2001). Therefore, strong competition between them could be possible, resulted in lower concentrations of $\mathrm{Na}$ in shoot and root in this experiment (Fig. 3). Moreover, both are positively charged cations. In some natrophilic plants, K can be replaced when $\mathrm{Na}$ content is high (Marschner, 1998). Similarly, opposite result could be expected in higher $\mathrm{KCl}$ solution in this present experiment. In sugar beet $\mathrm{Na}$ is readily translocated to the shoot where it replaces most of the K (Marschner, 1998). In this experiment, not only concentrations but also accumulations and translocations of $\mathrm{Na}$ decreased with the increasing $\mathrm{KCl}$ concentrations in the nutrient solution (Table 1). Sodium concentration decreased by $41 \%$ in shoot and $56 \%$ in root in the $30 \mathrm{mM} \mathrm{KCl}$ treatment. Potassium concentrations increased by $75 \%$, $114 \%$ and $159 \%$ in shoot but the values were 13, 72 and $56 \%$ in root in 10,20 and $30 \mathrm{mM} \mathrm{KCl}$ treatments, respectively. The highest $\mathrm{Na}$ and $\mathrm{K}$ ratio in shoot and in root were obtained in the control treatment (Table 2). The ratio decreased gradually and significantly and the lowest value was in the $30 \mathrm{mM} \mathrm{KCl}$ treatment. This result indicated that the highly antagonistic relationships between $\mathrm{K}$ and $\mathrm{Na}$. When salinity is caused by $\mathrm{Na}$ salt, it may decrease $\mathrm{K}$ content in plant tissue by competition, as both of them have similar ionic radii at hydrated condition.

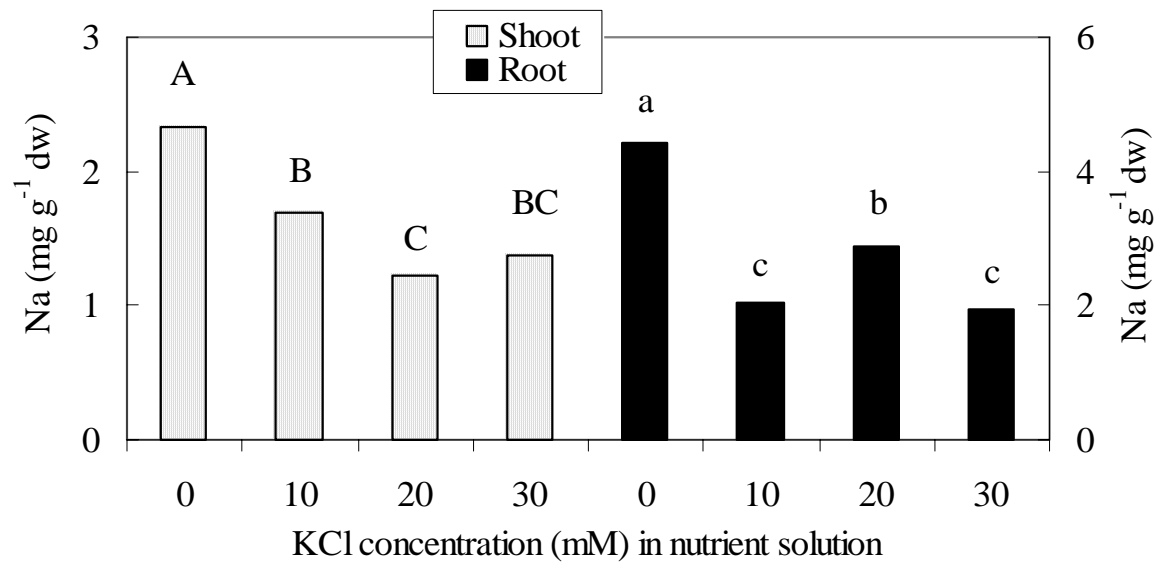

Fig 3. Effect of $\mathrm{KCl}$ on the concentration of $\mathrm{Na}$ in shoot and root of rice seedlings. Bars with different letters are significantly different $(p<0.05)$ according to a Ryan-EinotGabriel-Welsch multiple range test. 


\section{Critical toxicity levels (CTL) of $K$ in shoots and roots}

Considering $10 \% \mathrm{dw}$ reduction the CTL of $\mathrm{K}$ was calculated as $60.4 \mathrm{mg} \mathrm{g}^{-1} \mathrm{dw}$ in shoot and 23.3 $\mathrm{mg} \mathrm{g}^{-1} \mathrm{dw}$ in root, though the CTL were suggested to be very much dependent on the species and physical conditions of plants, varieties, environmental conditions especially temperature, nutrient compositions and methodology of the experiments. The CTL were calculated from the polynomial two order growth curves (Fig. 4ab) where the equations were $y=-0.0071 x^{2}-2.1289 x+733.86$ and $y=-0.1972 x^{2}+2.9083 x+224.02$ for shoot and root, respectively. For shoot, the highest growth was in control treatment and the value was $643.6 \mathrm{mg} / 5$ plants and the $10 \% \mathrm{dw}$ reduction was calculated from this value. In case of root, the value of control treatment was $205.4 \mathrm{mg} / 5$ plants and the value was used for the determination of CTL in root. By using the similar equations the CTL of arsenic (As) were reported by the present author in rice, sorghum and barley (Shaibur et al., 2008).
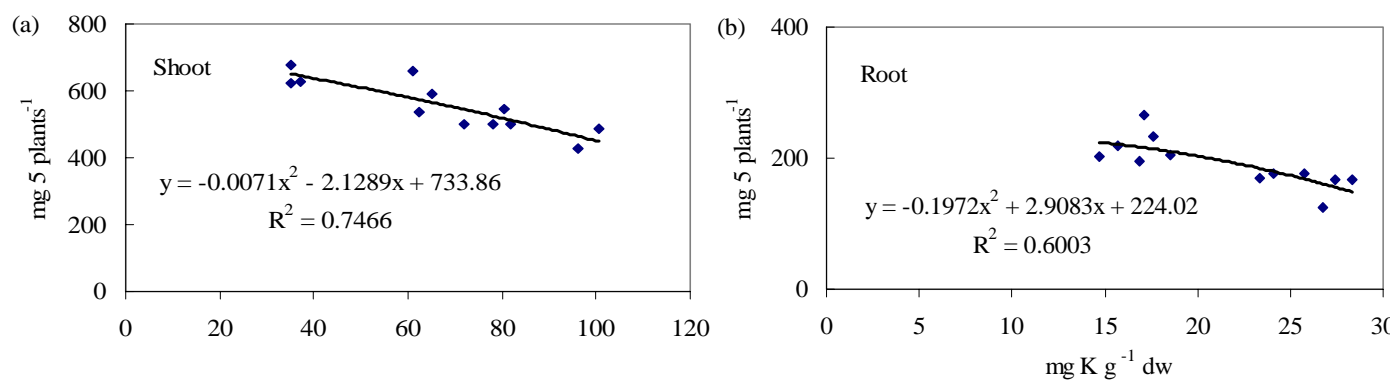

Fig 4. Two order polynomial growth curve (a) shoot and (b) root of rice seedlings with different $\mathrm{KCl}$ concentrations in plant tissues

\section{CONCLUSION}

The dry weight decreased significantly in shoot in the $10 \mathrm{mM} \mathrm{KCl}$ treatment, but in root the significantly reductions were obtained in 20 and $30 \mathrm{mM} \mathrm{KCl}$ treatments. Shoot height, root length and leaf number decreased significantly in 20 and $30 \mathrm{mM} \mathrm{KCl}$ treatments, but width of leaf blade decreased in the $30 \mathrm{mM} \mathrm{KCl}$ treatment. Therefore, rice plants could usually be classified as obligate glycophytes where shoots were more sensitive to $\mathrm{KCl}$ than that of roots. The critical toxicity levels (CTL) of $\mathrm{K}$ were $60.4 \mathrm{mg} \mathrm{g}^{-1} \mathrm{dw}$ in shoot and $23.3 \mathrm{mg} \mathrm{g}^{-1} \mathrm{dw}$ in root. From this experiment it could be concluded that $\mathrm{K}^{+}$shows the antagonistic relationships with $\mathrm{Ca}, \mathrm{Mg}$ and $\mathrm{Na}$ in rice seedlings. The decrease of $P$ concentration was most probably due to the toxic effect of $30 \mathrm{mM} \mathrm{KCl}$ treatment on rice seedlings. Phosphorus, $\mathrm{Ca}, \mathrm{Mg}$ and $\mathrm{Na}$ concentrations decreased in shoot by 12 , 22, 30 and $41 \%$ in the $30 \mathrm{mM} \mathrm{KCl}$ treatment, but for root the values were $9,27,33$ and $56 \%$, respectively. Considering the reduction value of concentrations, the sensitivity of these elements can be arranged as $\mathrm{Na}>\mathrm{Mg}>\mathrm{Ca}>\mathrm{P}$ both for shoot and root in rice seedlings when $\mathrm{KCl}$ is present at $30 \mathrm{mM}$ level. From our result it was suggested that small amount of $\mathrm{KCl}(10 \mathrm{mM})$ could be the good fertilizer for the rooting crops as the root growth increased significantly in the $10 \mathrm{mM} \mathrm{KCl}$ treatment, though this suggestion needs to be verified. In most cases it was found that $\mathrm{KCl}$ decreased the concentrations of $\mathrm{P}, \mathrm{Ca}$ and $\mathrm{Mg}$. The concentrations of macroelements were within the normal concentrations of plant nutrition but the plant growth decreased. Therefore, it could be suggested that the reduction of growth was associated with the reduction of macroelements concentrations together with the production of toxic biochemical substances which needs to be investigated.

\section{LITERATURE CITED}

Abedin, M. J, and Meharg, A. A. 2002. Relative toxicity of arsenite and arsenate on germination and early seedling growth of rice (Oryza sativa L.). Plant and Soil 243, 57-66.

Alam, S., Kamei S. and Kawai S. 2001. Amelioration of manganese toxicity in barley with iron. J Plant Nutri 24(9), 1421-1433.

Aronson, J. A. 1989. Haloph. "A Data Base of Salt Tolerant Plants of the World". Office of Arid Lands Studies, University of Arizona, Tempe, AZ. 
Barton, C. J. 1948. Photometric analysis of phosphate rock. Analyt Chem 20, 1068-1073.

Bernstein, L. 1975. Effects of salinity and sodicity on plant growth. Ann Rev Phytopath 13, 295-312.

Biggin, P. C, Smith, G. R., Shrivastava, I., Choe, S., Sansom M. S. P. 2001. Potassium and sodium ions in a potassium channel studied by molecular dynamics. Biochimi et Biophys. Acta 1510, 1-9.

Brady, N. C. and Weil, R. R. 2002. "The Nature and the Properties of Soils" (Thirteen Edn.). N. C. Brady and R. R. Weil, Prentice Hall, New Jersey.

Caldwell, C. R. and Haug, A. 1981. Temperature dependence of the barley root plasma membranebound $\mathrm{Ca}^{2+}$ and $\mathrm{Mg}^{2+}$-dependant ATPase. Physiol Plantarum 53, 117-124.

Cramer, G. R., Läuchli, A. and Polito V. S. 1985. Displacement of $\mathrm{Ca}^{2+}$ by $\mathrm{Na}^{+}$from the plasmalemma of root cells. A primary response to salt stress? Plant Physiol 79, 207-211.

Egan, T. P., and Ungar, I. A. 1998. Effect of different salts of sodium and potassium on the growth of Atriplex prostrata (Chenopodiaceae). J Plant Nutri 21(10), 2193-2205.

Greenway, H. and Munns, R. 1980. Mechanisms of salt tolerance in nonhalophytes. Ann Rev Plant Physiol 31, 149-190.

Greenway, H. and Osmond C. B. 1972. Salt responses of enzymes from species differing in salt tolerance. Plant Physiol 49, 256-259.

Glenn, E. P. 1997. Mechanisms of salt tolerance in higher plants. In "Mechanisms of Environmental Stress Resistance in Plants". (A. S. Basra and R. K. Basra, Eds.), Harwood Academic Publishers, Amsterdam pp. 83-110.

Heenan, D. P. and Campbell L. C. 1981. Influence of potassium and manganese on growth and uptake of magnesium by soybeans (Glycine max L. Merr. cv. Bragg). Plant and Soil 61, 447-456.

Hewitt, E. J. and Smith T. A. 1975. Experimental methods for the investigation of plant nutrient requirements. In "Plant Mineral Nutrition" (E. J. Hewitt and T. A. Smith., Eds.). The English Universities Press Ltd., London. pp. 30-52.

Jackson, M. L. 1958. Total elemental phosphorus. In "Soil Chemical Analysis" Prentice-Hall, Inc. Englewood Cliffs, New Jersey. pp.175-176.

Kurvits, A. and Kirkby, E. A. 1980. The uptake of nutrients by sunflower plants (Helianthus annuus) growing in continuous flowing culture system, supplied with nitrate or ammonium as nitrogen source. Z Pflanzenernähr Bodenk 143, 140-149.

Liao, X. Y., Chen, T. B., Lei, M., Huang, Z. C., Xiao, X. Y. and An, Z. Z. 2004. Root distributions and elemental accumulations of Chinese brake (Pteris vittata L.) from As-contaminated soils. Plant and Soil 261, 109-116.

Legge, R. L., Thompson, E., Baker J. E. and Lieberman, M. 1982. The effect of calcium on the fluidity and phase properties of microsomal membranes isolated from postclimacteric Golden Delicious apples. Plant Cell Physiol 23, 161-169.

Marschner, H. 1998. "Mineral Nutrition of Higher Plants" (Second Edn.). Academic Press, London.

Mengel, K. and Kirkby E. A. 2001. Iron. In "Principles of Plant Nutrition" (Fifth Edn.). (K. Mengel and E. A. Kirkby, Eds.), Kluwer Academic Publishers, Dordrecht.

Nilsen, E. T. and Orcutt, D. M. 1996. "The Physiology of Plants Under Stress: Abiotic Factors" John Wiley \& Sons, New York.

Orcutt, D. M. and Nilsen E. T. 2000. "Physiology of Plants under Stress: Soil and Biotic Factors". D. M. Orcutt and E. T. Nilsen Eds. John Wiley \& Sons, Inc., New York.

Piper, C. S. 1942. "Soil and Plant Analysis". Hassell Press, Adelaide.

SAS. 1990. "SAS/STAT User's Guide" (Version 6, Forth Edn.). Vol. 2. Statistical Analysis System (SAS) Institute, SAS Campus Drive, Cary, NC.

Shaibur, M. R., Kitajima, N., Sugawara, R., Kondo, T., Alam, S., Imamul Huq, S. M. and Kawai, S. 2008. Critical toxicity level of arsenic and elemental composition of arsenic-induced chlorosis in hydroponic sorghum. Water Air Soil Pollut DOI 10.1007/s11270-008-9624-0.

Shaibur, M. R, Kitajima, N., Sugawara, R., Kondo, T., Imamul Huq, S. M. and Kawai, S. 2006. Physiological and mineralogical properties of arsenic-induced chlorosis in rice seedlings grown hydroponically. Soil Sci Plant Nutri 52(6), 691-700.

Taiz, L. and Zeiger, E. 2002. "Plant Physiology" (Third Edn.) (L. Taiz and E. Zeiger, Eds.). Sinauer Associates, Inc., Sunderland, Massachusetts.

Tan, K. H. 1998. "Principles of Soil Chemistry" (Third Edn.) (K. H. Tan, Ed.). Marcel Dekker, Inc., New York. 